\title{
Hemodynamics effects of adrecizumab in sepsis RAT
}

\author{
A Blet ${ }^{1,2,3^{*}}$, M Sadoune ${ }^{1}$, E Polidano ${ }^{1}$, R Merval $^{1}$, C Bernard ${ }^{1}$, JL Samuel ${ }^{1}$, A Mebazaa ${ }^{1,2,3}$ \\ From ESICM LIVES 2015 \\ Berlin, Germany. 3-7 October 2015
}

\section{Introduction}

Sepsis and septic shock still represent major health issues, with persisting high morbidity and mortality rates in critically ill patients. Cardiac dysfunction [1] occurs frequently during severe sepsis.

Adrenomedullin (ADM) has been identified as a key mediator in vascular tone regulation $\left[{ }^{1}\right]$. A newly developed anti-ADM antibody Adrecizumab (ADZ) may improve hemodynamic dysfunction during resuscitated murine, cecal ligation and puncture (CLP)-induced septic shock [2].

\section{Objectives}

To determine the beneficial role of ADZ on hemodynamic impairment in a rat model of acute sepsis.

\section{Methods}

For induction of polymicrobial sepsis, cecal ligation and puncture (CLP) [3] was performed in Wistar male rats. ADZ $(2 \mathrm{mg} / \mathrm{kg})$ was injected IV $24 \mathrm{~h}$ after the surgery. There were 7 animals per group. Invasive blood pressure and cardiac function (by echocardiography) were assessed until 2 hours after ADZ injection. Statistical analysis was performed with 2 ways ANOVA.

\section{Results}

Septic rats had lower mean arterial pressure (MAP) $(p<$ $0.0001) 24 \mathrm{~h}$ after surgery (at baseline) compared to sham. Septic animas with ADZ had a trend to have a greater MAP. A transient decrease of SF was observed 15 min and $1 \mathrm{~h}$ after injection of $\operatorname{ADZ}(p=0.05)$. On the other hand cardiac output seems to be increased by $\operatorname{ADZ}(p=0.61)$.

\section{Conclusions}

During sepsis in rats, treatment by ADZ seems to have a beneficial effect on cardiac and vascular dysfunction. These preliminary results need to be confirmed in preclinical and clinical studies.

\section{Grant Acknowledgment}

Adrenomed.
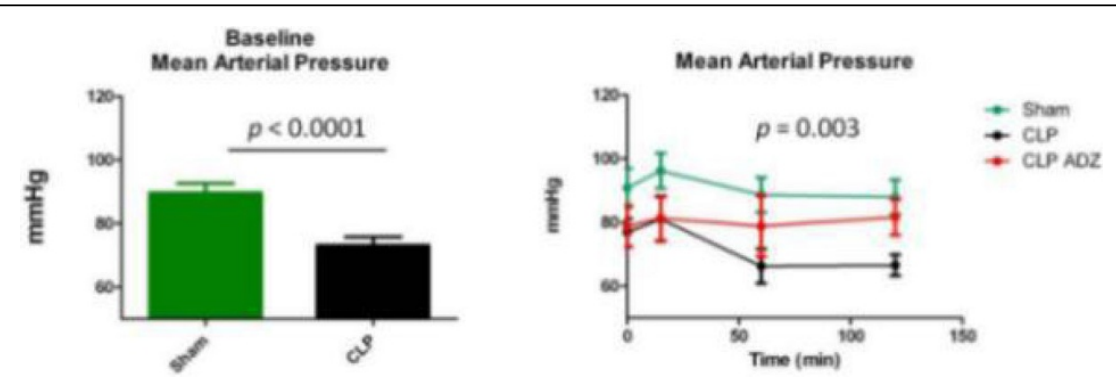

Figure 1 [Mean arterial pressure] 


\section{Authors' details}

${ }^{1}$ Inserm, UMR 942, Paris, France. ${ }^{2}$ GH Lariboisière Saint-Louis, APHP,

Department of Anesthesiology and Critical Care and Burn Center, Paris,

France. ${ }^{3}$ University Paris VII Denis Diderot, Paris, France.

Published: 1 October 2015

\section{References}

1. Nishio K, et al: Critical Care Medicine 1997, 25(6):953-7.

2. Struck, et al: Intensive Care Med Expe 2013, 1:3.

3. Rittirsch, et al: Nature Protocols 2009, 4:31-36, n¹.

doi:10.1186/2197-425X-3-S1-A618

Cite this article as: Blet et al: Hemodynamics effects of adrecizumab in sepsis RAT. Intensive Care Medicine Experimental 2015 3(Suppl 1):A618.

\section{Submit your manuscript to a SpringerOpen ${ }^{\circ}$ journal and benefit from:}

- Convenient online submission

- Rigorous peer review

- Immediate publication on acceptance

- Open access: articles freely available online

- High visibility within the field

- Retaining the copyright to your article

Submit your next manuscript at $\gg$ springeropen.com 